\title{
Crossing Borders And Managing RACIALIZED IDENTITIES: EXPERIENCES OF Security and Surveillance Among Young CANAdian Muslims
}

\author{
BaLJit NAgra \\ Paula Maurutto
}

\begin{abstract}
While it is widely acknowledged that Canadian Muslims are targeted at airports and borders, few studies have focused on their actual experiences of state surveillance practices. Moreover, little attention has been paid to how these experiences impact and shape identity formation and their understanding of citizenship. To address this gap, we conducted 50 in-depth interviews with young Canadian Muslims living in Vancouver and Toronto. Our interviewees referred to being repeatedly stopped, questioned, detained, and harassed by security personnel. They felt that any evidence of their Muslim identity - name, country of birth, appearance, or clothing - makes them a target for extra surveillance, resulting in heightened fears about being stripped of their rights and a lack of ability to assert their religious identities. This paper explores the implications of racialized border practices on identity formation and citizenship depletion among Muslim Canadians.
\end{abstract}

Keywords: Canadian Muslims, Muslim identity, race, racial profiling, surveillance, War on Terror.

Résumé. Alors qu'il est largement reconnu que les musulmans canadiens sont ciblés dans les aéroports et aux douanes, peu d'études se sont penchées sur leur expérience concrète face aux pratiques étatiques de surveillance. De plus, peu d'attention a été accordée à la façon dont ses expériences de surveillance ont eu un impact sur la formation de l'identité des musulmans canadiens et leur compréhension de la citoyenneté. Afin de combler cette lacune, nous avons réalisé 50 entrevues en profondeur avec de jeunes musulmans canadiens résidants à Vancouver et à Toronto. Nos interviewés ont exprimé avoir été arrêtés, interrogés, détenus et harcelés par le personnel de sécurité de manière répétitive. Ils ont indiqué que toute preuve de leur identité musulmane, leur nom, pays d'origine, apparence physique ou vestimentaire, augmente leur risque d'être 
la cible de surveillance additionnelle, résultant en une peur accrue de leur part d'être déchus de leurs droits et une incapacité d'exprimer pleinement leur identité religieuse. Cet article explore les implications des pratiques racialisées de surveillance frontalière sur la formation de l'identité des musulmans canadiens et sur la fragilisation de leur citoyenneté.

Mots-clés: Musulmans canadiens, identité musulmane, race, profilage racial, surveillance, guerre contre le terrorisme

\section{INTRODUCTION}

A irports, and borders more generally, are spaces where travel is contingent on individual agreement to surveillance and identity checks (Fuller and Harley 2004). In these spaces, individual identities are recorded, questioned, risk profiled, and biometrically assessed to differentiate what are perceived to be "legitimate screened travellers" from those with "suspect identities." In the "War on Terror," the rhetoric of promoting secure borders has resulted in practices that are reshaping the relationship between the nation state, citizenship, and identity, particularly among Muslim communities. This paper explores how these practices are experienced by Canadian Muslims in an effort to understand how they impact identity formation and citizenship.

Mobility across boarders has become increasingly subject to intensive routine surveillance (Hiller 2010; Lyon 2003; Lyon 2008). The events of 9/11 affected travel for everyone, however some groups are impacted more than others (Poincignon 2004). New forms of social sorting (Lyon 2003) that produce labels such as "terrorist," "security threat," and even "suspicious" are powerful identity categories that have significant implications for movement - but also civil liberties and due process rights. The border has been described as a place of "banishment" (Butler 2004), a "state of exception" where the rule of law can be suspended indefinitely (Salter 2008; Krueger et al. 2008; Agamben 2005), or as a "legal manifestation of white hegemony" that perpetuates the subordination of marginalized groups (Said 1985). These are spaces where nation states legitimize the stripping away of rights away in the name of security (Zedner 2010) and where "citizenship status can be substantially depleted" (Muller 2004; Aas 2011; Thobani 2007).

Concerns about the effects of surveillance practices at borders on Muslim communities have increased over the last decade (Helly 2004; Akram and Johnson 2002; Bhabha 2003; Bhadi 2003; Choudhry 2001; Choudhry and Roach 2003; Sharma 2006; Bhandar 2008; Jamil and 
Rousseau 2012). Anti-terrorism policies and practises in Western countries are said to hide "endemic problems of racism and discrimination affecting the lives of Muslims who find themselves routinely surveyed, suspected and questioned" (Mythen et al. 2009: 73; Macklin 2007; Razack 2008; Ahmed 2011; Thobani 2007). The racism and discrimination experienced by minorities through these practices are not isolated consequences of poorly conceived counter-terrorism laws. They are endemic phenomena, expressed through and across institutional discourses and practices (Naber 2006; Razack 2009; Thobani 2007; Mirza et al. 2007, Arat-Koc 2005; Macklin 2007; Zine 2012). However, relatively few studies focus on how Muslims experience surveillance at the border and how this shapes their identities and citizenship. The limited studies that explore these issues have focused on the experiences of Muslims in the UK (Mythen et al. 2009; Mythen et al. 2013). To address this gap, we explore the implications of racialized border practices on the lives of young Canadians Muslims. We also examine how the experience of being the target of security practices solidifies their Muslim religious affiliation but how it also gives rise to a range of identity management practices that are most apparent at airports and borders.

We interviewed young Canadian Muslims, and found that that the border is a contentious site where members of this group experience heightened intimidation, fear, and hostility. We conducted 50 interviews with Muslims living in Toronto or Vancouver from 2005 to 2010. Our sample included 24 men and 26 women, aged 18-31. Approximately 70 percent of Muslims living in Canada reside in metropolitan areas (Statistics Canada 2011). Each semi-structured in-depth interview lasted approximately one hour. Interviews were audio-recorded, transcribed, coded thematically, and then analyzed using N-VIVO qualitative analysis software program. The interviewees were guaranteed anonymity and have been given pseudonyms in this paper. Interviewees were asked about their experiences crossing borders, how they deal with the increased surveillance they encounter, and how these experiences affect their identity. Participants were recruited using a variety of strategies including personal networks, snowball sampling, and through Muslim student organizations at the University of Toronto and Simon Fraser University. All participants self-identified as Muslim. Most (82\% or 41/50) were Canadian citizens; of these, 40 percent (20/50) had been born in Canada and 42 percent $(21 / 50)$ were naturalized citizens. Nine interviewees had been living in Canada for five years or less. Of those not born in Canada, countries of origin were diverse and included India, Pakistan, Fiji, the West Indies, Libya, Bangladesh, Egypt, Saudi Arabia, and East Africa. Participants represented a variety of Muslim traditions, 
including Ismailia, Shia, and Sunni, and spoke various languages. Of the female interviewees, twelve reported regularly wearing a hijab (head scarf).

The findings discussed in this paper represent the patterns that emerged from our research and the quotes selected are reflective of the commonalties in the interviewees' experiences. We use our interviewees' experiences as evidence of real practices in society, not merely subjective accounts or isolated individual experiences. In doing so, we link our interviewees stories to broader social patterns. Frances and Tator (2006) convey that while the dismissal of the lived experiences of racial minorities through claims that they represent "perceptions" and "subjective experiences" is pervasive practice in academia and in public discourses, these experiences are in fact "a body of systematic evidence of individual and systematic racism directed against people of colour" (2006: 122). Taking these insights into account we utilize our interviews as a methodological approach to understand how racialized border practices work to stigmatize young Canadian Muslims, diminish their Canadian citizenship and impact their identity formation.

In order to contextualize Canadian Muslim's experiences, the following begins with an overview of Canada's anti-terrorism reforms, legislations and reviews of the literature on racial profiling at the border. This review situates the context within which our participants are located. We then explore our participants' experiences of profiling at borders and airports. This analysis considers how security configurations adopted at border crossings impact Canadian Muslims understanding of citizenship and shape how they enact their identity. Understanding the range of their experiences as they cross national and international borders helps clarify the consequences of new security configurations in Canada.

\section{CANAdA's ANTi-Terrorist Legislation: Understanding the Political and Legal Context}

Since 9/11, new security configurations in Western countries have had decidedly different effects for diverse groups in society (Spencer 2006; Pantaziz et al. 2009). The "War on Terror" is qualitatively distinct from previous terrorism concerns, and has introduced new and evolving mechanisms of security control that differ from those used previously, for example, during the Cold War era (Lyon 2003). The "new terrorism" positions religion, specifically "Islamic fanaticism," rather than political or ideological differences, as the greatest threat to Western liberal democracy (Howard and Sayer 2004). Prior to the tenth anniversary of 9/11, 
Canadian Prime Minister Stephen Harper announced that the most pressing threat to Canada "is still Islamicism" and that Canada's security and intelligence service are primarily "preoccupied with Islamic extremism" (CBC News, 9 Sept 2011).

This kind of discursive and political coupling of Islam with terrorism is strategically mobilized by nation states and politicians to justify a new security configuration (Ahmed and Spalek 2011). Muslims are depicted as the risky, dangerous, and deviant Others, unable to adapt to Western traditions (Alexander 2000). Islam problematically has come to symbolize "the axis of evil" determined to terrorize and devastate the West, and Muslims are constructed as a risky "suspect population," the "new folk devil," or "the enemy within" (Kundnani 2002; Fekete 2004; Pantazazi et al. 2009), reminiscent of descriptions of the "barbaric other" described in Said's influential work on Orientalism (1981). These tropes are selectively invoked to reinforce the "War on Terror": they are strategically mobilized by nation states and politicians to justify differential treatment, the curtailment of civil rights, and the enactment and reinforcement of extreme counter-terrorism practices.

While Canada's anti-terrorism practices may not be as extreme as those in the US or Britain, Canada is part of the Western trend towards enhanced national security and the building up of extreme counter-terrorism laws that have shifted the balance between security and civil rights. Canada's Anti-Terrorism Act, enacted in December 2001, modified 22 existing laws, including the Criminal Code, the Aeronautics Act, and laws affecting the protection of personal information, access to information provisions, and request for evidence (Helly 2004). The Act was highly controversial because of its perceived dismantling of protected Canadian civil liberties inscribed in the Charter of Rights and Freedoms. Similar to the U.S. Patriot Act, it allows for "investigative hearings," preventative detention, and the expansion of surveillance powers. These new strategies increased the powers of the police to deal with potential terrorists or acts of terrorism, and more specifically, allowed the police to arrest suspects without a warrant and hold them for three days without charges. This legislation also led to the creation of new criminal offenses, such as facilitating and enticing terrorist acts (Helly 2004; Poynting and Perry 2007). Initially, these amendments were subject to a sunset clause and were to be time-limited, but in April 2013, Bill S-7, the Combating Terrorism Act, was passed in the House of Commons. This Act renewed and reformed many of the provisions of early anti-terrorism legislation; it also imposed stiffer penalties and introduced a new prohibition against individuals leaving Canada to commit terrorism abroad (Parliament of Canada 2013). Recently, Canada has also introduced Bill C24 and Bill 
C51 with the former allowing for the revocation of citizenship for committing national security offenses (Black 2014) and the latter broadening the surveillance power of CSIS and enhancing the internal sharing of information across all government departments (Forcese and Roach 2015; Hameed and Nagra 2014).

These legislative initiatives have been highly controversial and have been extensively criticized by both academics and legal experts (Forcese 2014; Macklin 2014; Forcese and Roach 2015; Hameed and Nagra 2014). Academics have argued that these new measures enable the Canadian Security Intelligence Services (CSIS) and Royal Canadian Mounted Police (RCMP) to collect intelligence from people active within the Muslim community and from Muslims whose immigration status is uncertain (Helly 2004; Poynting and Perry 2007). People who appear to be Muslim or Arab face more scrutiny due to this discretionary power (Bahdi 2003). Increasingly, antiterrorism legislation has sought to target not only threats external to the country, but are designed to root out a presumably growing internal threat. The rhetoric promoted though these forms of legislation suggests that Muslim communities are incubators of terrorism, thereby, justifying the targeting and denial of full citizenship rights to those belonging to these communities (Thobani 2007; Razack 2008; Zine 2012).

\section{RACIALIZEd Borders}

Canada has historically policed its borders through racial lines (Dua 2000; Anderson 1991; Razack 2008, Helleiner 2012, Thobani 2007, Sharma 2006, Bhandar 2008). Dating back to the first half of the century, rigid forms of border controls were implemented that favoured "White" immigrants, limited Asian and South Asian migrants into Canada and placed mobility restrictions on Indigenous populations. (Simpson 2008, Sharma 2006, Bhandar 2008, Thobani 2007). These racialized colonial mechanisms for structuring society and classifying populations continue to linger and are reinforced through new technologies and practices that are promoted as "scientific" and rational forms of surveillance (Sa'di 2012). Practices of racial profiling or what Brown (2012) refers to as "racialized surveillance" continue to infuse and inform both who we let into our country and how we police our borders. Significantly, Bhandar (2008:281) remarks "the production of differentiated racial ontologies of immigrant/migrant communities situated within the nation state" is often produced through mechanisms of racial profiling at the border. 
Several Canadian studies have documented the prevalence of racial profiling at the border (Abbas 2005; Poole 2002; Helleiner 2012; Pratt 2010; Sharma 2006). Moreover, in the Supreme Court of Canada case R v. Simmons [1988], the court upheld the constitutionality of searches based on reasonable "suspicion." According to Tanovich (2006:13) racial profiling occurs "when law enforcement or security officials, consciously, or unconsciously, subject individuals at any location to heightened scrutiny based solely or in part on race, ethnicity, Aboriginality, place of birth, ancestry, or religion, or on stereotypes associated with any of these factors, rather than on objectively reasonable grounds for suspecting that the individual is implicated in criminal activity". These practices are commonly exercised by border officers in their daily routines. As Pratt and Thompson (2006) point out, border officials engage in racial profiling by drawing upon racialized risk knowledge that include eclectic blends of race, ethnicity, culture, religion and nationality. More recently, reports commissioned by both the Canadian Human Rights Commission (2011) and the International Civil Liberties Monitoring Group (2010) have raised alarms over the excessive use of racial profiling at airports, particularly when screening Muslim and Arab communities. Since 9/11, as Cunningham (2004) argues, there has been a "rebound" in the extent to which racial profiling is being used to assert control over national landscapes. And as Badhi points out, the central contention is "no longer whether racial profiling [is] in fact taking place...but whether Canadian society can morally, legally, or politically condone racial profiling" (2003: 295).

In the post 9/11 world the threat of potential "Muslim terrorists" has become the strongest rationale for increasing regressive border policies throughout the global North, making the racial profiling and targeting of Muslim identity central to border management (Sharma 2006). As Zedner (2010) posits, racial profiling in the post 9/11 world includes a new security architecture that targets and racializes a whole group of different ethnicities, Islamic religious traditions, and culture as the Muslim "other". In state surveillance practices this "othering" occurs through the use of multiple characteristics; skin colour, name, country of origin, and religious markers meld together to make Muslims highly visible as suspect figures (Naber 2006; Jamil and Rousseau 2012). The suspicion of the "other" sticks to their bodies, resulting in the perception of Muslims as objects of fear (Ahmed 2000). As a result, Muslims experience risk subjectification, "a process through which they become defined as dangerous by virtue of sharing some characteristic of the "typical terrorist"” (Mythen 2013: 390). Within this context, "risk" has less to do with individual behaviour than with how Muslim identity has been racialized. 
Academics have noted that given the barriers faced by Muslim travellers, crossing borders becomes a process of identity management (Muller 2004) where they have to continuously perform "safety" (Mythen 2009).

For Muslims and other targeted groups, the implementations of these measures results in a perception that borders have become a "state of exception" where fundamental rights and freedoms are eroded in the name of security (Agamben 2005). Razack (2008) elaborates on how the state of exception is underpinned by a racist ideology that posits modern enlightened secular people (the West) as needing to protect themselves from pre-modern religious people (Muslims) through any means deemed necessary. The logic is a colonial (and Orientalist) one: the perception is that they are not like us and are likely to erupt in violence. Or, as Razack (2008) argues, they are marked at a different level of humanity and assigned a separate and unequal place in law. Airports, and more broadly border crossings, then emerge as spaces where Muslims can be legally stripped of their citizenship or legal rights and find themselves in an "indefinite" suspension of law where transgressions of individual rights can be deemed lawful. Anti-terrorism legislation is both derived from and operates to mask longstanding colonial practices that differentiate between groups of citizens.

Racialized border practices, in particular, present serious repercussions for national belonging, as claims to citizenship are arbitrated in these spaces (Salter 2007; Helleiner 2010). Salter (2007:59) writes "travelers are reduced from citizens, foreigners, refugees, with complex identities and claims to home into objects of danger or benefit, which perhaps afford entry or exit into the national population." Borders then become ways to create multiple differential exclusions rather than just instruments to restrict access to national territories (Sharma 2006). These different exclusions are produced when those that are seen as "us" or as "real" citizens are granted entry and, those that are designated as "dangerous" and "others" are subject to scrutiny and surveillance (Mythen et al 2013).

This differentiation between groups has significant implications for understandings of citizenship and allows for what Aas describes as a "groups of subcitizens", who, although territorially included, find their kinship status securitized and substantially depleted" (2011: 340). According to Zedner (2010), the citizenship status of Muslims who have become Canadian, American or British is often perceived as "irregular" or "flawed", and as a result they are treated as sub citizens. This then becomes the means for legitimating differential policing practices. Although members of this group still have rights, they live in constant fear 
of having these rights eroded (Bhabha 2003; Bahdi 2003; Sharma 2006; Razack 2008; Zine 2012; Jamal and Rousseau 2012).

It is within this context that our participants are situated. Our examination of Canadian Muslim's experiences reinforces the work of previous scholars and offers a unique analysis of how our interviewees experience this "othering". Our study explores how Canadian Muslims experience racialized border practices, its problematic implications on their lives, and its impact on identity formation and sense of citizenship.

\section{Profiling Muslim Identity}

A common theme to emerge from our interviews is the shared perception that borders are spaces where Muslims experience extreme forms of discriminatory, and most often offensive and demeaning, treatment. Our interviewees reported being frequently stopped, questioned, detained, and subjected to secondary screening. The majority of our participants, some 98 percent ( 49 of the 50) believed that racial profiling of Muslims was pervasive at borders. Sixty percent of the interviewees, 30 out of 50 felt unfairly scrutinized (i.e. through the asking of extensive questioning, secondary screenings and/or intrusive searches) by security personnel at airport and land crossings because of their Muslim identity. This group of interviewees included an equal representation of men and women. The 20 participants who did not report direct experiences of racial profiling tended to have travelled less frequently since $9 / 11$. Some 78 percent, (39/50), recounted stories of when their family or friends experienced racial profiling at airports and land crossings. There was a strong feeling among our interviewees that they and their family/friends disproportionately faced these experiences compared to other travellers. What became clear to us in our research was that our interviewees saw the border as a contentious site where they, their friends and family can be legitimately stripped of their citizenship rights and subject to derogatory treatment.

Our interviewees recalled a total of 81 incidents (participants indicated there were many more experiences than the total described in interviews) where either they or someone they knew felt scrutinized by security personnel at airports and land crossings as a result of their Muslim identity. Some 90 percent of these incidents occurred in North America with three percent occurring in various other borders in Europe and Israel. Fifty-seven of these incidents (70 percent) occurred at airports, and 24 (30 percent) at land border crossings, indicating that our participants were more likely to travel through airports. While we acknowledge that airports and land crossings are different spaces, our interviewees did not 
appear to distinguish between the two. Instead, they saw commonalities in the discriminatory practices they experienced in both locations. Hence, our analytical focus in this paper is with the cumulative effect of security measures at borders on young Canadian Muslims, and not in examining differences between airport and land crossings. However, future studies that examine the differences in these spaces could reveal important findings on how racial profiling operates across different sites.

Our interviewees noted that in their secondary screenings, they faced extensive forms of interrogation and intrusive searches by security officials. Participants referred to repeat questioning by border officials and how they perceived this as a mechanism designed to intimidate and mistakenly "trip them up." They recalled being questioned at length about their religious beliefs, travel plans, life in Canada, and their background. Samir, a 23-year-old male who immigrated to Canada from India as a child, and Atiya, a hijab-wearing, 31-year-old woman who was born in Canada to a Pakistani family, explained:

If you're travelling with a group, you'll be taken in separate interrogations and you'll be asked really specific questions. Even if one question happens to be a little bit off from maybe one of your peers, even if it's the most irrelevant thing like, 'How long have you lived at your current residence?' Maybe your sister will say three years, and maybe you'll say two years. Something as insignificant is taken as 'Oh, maybe they're hiding something. This is their story, they messed up.' (Samir)

They usually try to trip me up at the border by asking me a lot of questions. They will be like 'have you ever been denied at the border' and I will be like 'no.' They will be like 'aren't you and so' and I will be like 'no.' So they try to trip me up by asking these questions and try to make me nervous. (Atiya)

These two accounts exemplify the experiences reported by many participants. Respondents reported being questioned extensively about their religious beliefs, how religious they were, and which Muslim sect they belong to. For our respondents, this line of questioning made them feel like "suspected criminals" who had to prove their innocence. By comparison, they felt that other groups - specifically "Caucasians" - were not likely to be interrogated about their religious practices.

Interviewees recounted how any sign of their Muslim faith, be it name, country of birth, appearance, or clothing, could result in extra questioning and searches. Participants with typical Muslim names claimed to be more likely to be singled out for extra surveillance. For instance, Zaahir, a 22-year-old man who immigrated to Canada at the 
age of four from Saudia Arabia, and Aatifa, a hijab-wearing 24-year-old woman who arrived from Saudi Arabia at the age of 13, mentioned the following:

Actually one time I went to the airport with my brother in law. The lady actually pick[ed] up the phone and said "I have one of those people with names," so that sort of stuff. I think it's kind of silly. (Zaahir)

I have a friend whose name is Mohammed and every time he travels, he is detained for a very long time. They do all these checks on him and once things got to the point where he missed his flight. (Aatifa)

Our interviewees also felt that non-Muslims of Middle Eastern or South Asian descent who tend to have darker skin, were also viewed with suspicion and subjected to additional screening. Bushra, an 18-year-old Muslim woman born in Canada from an Indian and East African background, recalled that in 2007 while on an international high school trip, Muslims along with non-Muslim Indian students were picked out for additional security checks, while the rest of the class was left alone. She recounted how obvious the intended targets were; there was no attempt to randomly select students. Other interviewees also recalled similar occurrences.

Country of origin was also perceived as a significant marker in racial profiling of Muslim identity. A number of interviewees felt they were subject to increased surveillance because they were born in the Middle East or came from a South Asian country like Pakistan. For instance, Aatifa, said the following:

Crossing the border on the road is difficult because immediately they get to see your passport and where you were born. I am Canadian but my sister and I were born in Saudi Arabia, so bells just go off right then and there.

Significantly, Pratt and Thompson (2008) find that border officials often conflate race and nationality to reproduce racialized decision making at the border. Our interviewees' experiences reinforce these findings by documenting how participants felt treated as dangerous "others" by the simple virtue of their country of birth.

Our interviewees also felt that looking more "Muslim" by the wearing the hijab or having a Muslim beard made one more likely to be stopped and searched. Interviewees mentioned that their relatives and friends who wore the hijab felt they experienced heightened surveillance at airports and land crossings. Of the 26 female interviewees, 12 (67\%) 
regularly wore the hijab, and all of them recounted how they often were asked to remove their hijab when going through security checkpoints at airports. They felt harassed by security personnel during these occurrences. These women claimed that for the West, the wearing of the hijab is perceived as a threat and used to legitimize increased surveillance, and even hostility and harassment. For instance, Maria, a hijab wearing, 23-year-old woman born in Canada with parents from Tanzania, claimed that:

I think it has to do more with making you feel discomfort. After going through ten security checkpoints, what are you going to hide in your hijab? What about sweaters, shirts? You are asked about your hijab. You're not asked about your pants. Does it make any sense? I think its discrimination. Although I comply, I know there's no reasoning behind it.

Wearing the hijab has become politicized in many contexts. It is often problematically associated with terrorism, radical politics, and a rejection of Western values (Ahmad 2002; Fekete 2004). At the border this kind of religious symbol may become an automatic marker of risk. While these women expect to be singled out at border crossings, what they feared most was being subjected to derogatory treatment by border officials.

A common theme to emerge from our interviews was the pervasive feeling of deception that participants felt when border officials or governments denied racial profiling at the border. Our participants identified racial and religious profiling as a common practice, yet, they claimed that border officers consistently denied any racial profiling, and maintained that participants' were randomly selected. Leela, a 20-year-old Muslim woman born in Canada with Indian-East African heritage recounted how:

Once my family went on a trip and at the airport they made us take our shoes off. But we were the only one's that had to take our shoes off in the line. We were like "why are we being discriminated against?" And then they would make up things like, "Oh it is just a random check". Once they pulled us out to the side and they checked every piece of the luggage but left everyone else alone. And when we asked why, they said "it's random".

Similarly, Yazeed, a 21-year-old man who was born in the Sudan and came to Canada when he was 12 years old, remarked:

They say they have 'random' checks, but they don't seem random to me because I do get checked every time I go through them. They say it's a "random" check, but I do always get checked. Chance alone says it shouldn't be happening. 
Our interviewees' interpreted statements like "it's random" as a coverup by border officials designed to obscure the pervasive discriminatory practise of profiling Muslims. Our findings echo Pratt and Thompson (2008) study, which found that border officials often use the ambiguity surrounding the meaning of racial profiling to make official denials, in order to conceal their pervasive use of racial profiling at borders. By claiming searches are random, border officers avoid serious scrutiny while maintaining institutionalized race-based practices (Pratt 2010). Furthermore, Frances and Tator (2006) believe that the refusal to admit to the reality of racism is in fact a form of racism. They argue denials of racial profiling among policing and other institutional authorities is tied to democratic racism in Canada - an ideology that posits that Canada cannot be racist because it is nation committed to equality, justice and fairness. For our interviewees, having incidents of racial profiling denied through claims of "random" procedures worked to minimize and invalidate their experiences of discrimination.

A particularly disturbing aspect of racial profiling for our interviewees, was their treatment by security personnel, once they had been picked out for additional screening. Interviewees referred to various practices of intimidation, victimization, and harassment. Zora, a hijab wearing 22-year-old woman, who was born in Bangladesh and came to Canada when she was eight, told us:

It was not the questions themselves, but the manner in which they were asked that was quite aggravating. They were trying to provoke us. The guy was pretty sarcastic in his tone. Like, it's obvious that I am Muslim, but he's like, "What's your religion?"

Alisha, a hijab-wearing, 26-year-old woman who immigrated to Canada at the age of 20 from Pakistan, explained:

They [security personnel] just direct you more. They try to be more rude. And they just try to have this thing, like this, not superiority, they... just try to be hard,... I don't know. ... just cause you're Muslim they try to be more rude so that you'll feel intimidated.

According to our participants, security personnel combine intensive searches with demeaning treatment, where our participants reported facing considerable hostility, yelling and anger. They felt victimized and harassed in a way that goes well beyond performing security. When their civil rights are being compromised, rather than being treated in a respectful manner, racial profiling practices appear to legitimate all kinds of degrading and humiliating treatment. Our findings resonate with the work Badhi (2003) and Chandrasekhar (2003) who note that officers 
have considerable discretionary and broad coercive powers which, when coupled with ingrained stereotypes, can result in behaviour that operates to demean, threaten, and victimize Muslims at the border.

What our interviewees found most disturbing and frightening was the victimization and harassment of children. Participants spoke of their concerns and feelings of helplessness to protect children exposed to state intimidation tactics when their parents or other family members are searched. Zeba, a hijab-wearing 22-year-old woman born in Canada from an Indian background, and Amineh, a 23-year-old hijab-wearing woman born in Canada to a Libyan family reported how:

My friends where driving down to the States through the border, and they've had their entire car searched; they've had dogs come around their car. They have small children in their car, and they've had the dogs come around their car. The kids got very upset. They've been withheld for about two, three hours at security. Like they could have taken the kids out of the car and then brought the dogs but they didn't. (Zeba)

The security people always harass us. Once my family was at the airport and this security guy gestured and said "these people are for me" and he made us go where he was. And my brother was an elementary school kid. He was sick and he was eating a cracker and the guy made my brother put the cracker there on the security belt. My brother was like "it is going to get dirty and I am not going to eat it then." And the guy was rude and said loudly to him "I don't care put it on the belt". And it was just a cracker. (Amineh)

Participants raised concerns about the fear and long-term impact of surveillance practices on children. The interviews spoke of the increased vulnerability of Muslim children as they cross borders. Little scholarly attention has been paid to the impact of surveillance on children. Our findings suggest that the status of being a "child" is erased once children or members of their families are perceived as "suspect" and, hence, they can be subjected to a broader range of surveillance tactics and techniques that can have long lasting negative impacts.

Missing flights because of prolonged searches, being detained indefinitely, or having themselves, friends, and family subject to stripsearches were common concerns shared by those interviewed. Amineh recounted her friend's experience of being strip searched:

I had a friend who was strip searched at the US airport. She was stripped to the bare and she did not even trigger off the metal detector and you are not supposed to strip search someone that does not trigger off the detector, so she sued them. 
For our interviewees, the border is understood as a space where traditional due process rights can be suspended and where they can be subjected to a range of intimidation, humiliation, and dehumanizing treatment by security officers.

\section{Diminished Citizenship}

Experiences and stories of racial profiling at the border are intertwined with their understandings of citizenship. The majority of the participants, 82 percent (41 out of 50) were Canadian citizens. Of these, 20 were born in Canada and 21 were naturalized citizens. For these Canadians, citizenship was presumed to be tied to rights and freedoms, in particular, the right of mobility, the right to safety and security, and the right to be protected from discriminatory state practices. Yet, their treatment at borders is perceived as positioning them as "accidental" citizens who are not "real" Canadians and, hence, can be legitimately treated as different. For example, Maria, who experienced considerable harassment at airports, reported that:

Muslims who are born in Canada, to everybody there are not considered Canadian; they are considered Canadian born. Which is a difference, because as Canadian, you are part of this country, you contribute to society, you have some sort of pride. Canadian born means you were just born in Canada. A Muslim born in Canada is considered Canadian born. They are not considered Canadian, which is so different.

Aaeesha, a 24-year-old woman who immigrated to Canada at the age of five from Pakistan, commented on how:

You could be a Canadian citizen, and you could have lived here for years, and yet they will stop you. I don't agree with that. And I find that they do that more and more. I think that the trust citizens had before $9 / 11$ is not there anymore.

Participants used terms like "accidental Canadian," "Canadian born," "hyphenated-Canadian" to describe how they would never be perceived as "real" Canadians and, hence, never be afforded similar treatment and rights enjoyed by "white" Canadians.

For Muslims who are naturalized Canadians, Canadian citizenship is always suspect. By continuously questioning their citizenship in the name of border management, officials made our participants feel as illegitimate members of the nation despite their Canadian citizenship. For instance, Dawoud, a 25-year-old who was born in Saudi Arabia and who immigrated to Canada as a young child, told us: 
They start off with a simple, "What do you do? When did you move to Canada?" I normally get picked up after they say, "Where were you born?" and I say Saudi Arabia and you see their expression change, and they immediately send me inside. So they ask questions like, "Why did you move to Canada?" and I'd say, "Well, my parents moved." And, "Why did they move?" "Well, they wanted a better education for their kids and a better future." "You're done your education now." "Yes." "Why haven't you gone back?" Like, "I'm not a Saudi citizen. I never was." I was a Pakistani citizen because Saudis don't give citizenship. And, I am a Canadian citizen now. It's my home. I look at it as my home. So sometimes the questions become very annoying. And, I've been asked that question every single time, "Why don't you go back?"

For our interviewees, this line of questioning reinforces that they are perceived as "outsiders inside"(Zedner 2010). But also, as Bannerji (2000) posits, the asking of populist nationalist questions from state officials and mainstream society, operates to discipline national identities. In our interviewees' case, such experiences compel them to manage their Muslim identities, as discussed in the following section.

Our interviewees who were naturalized citizens felt having their passports reveal where they were born placed them at risk for having their rights as Canadian citizens eroded. As Lyon (2008) documents, security officials use passports to make various distinctions between legitimate citizens and "others." Zaahir, a 22-year-old man who came to Canada when he was four from Saudi Arabia, remarked that:

Coming back to Canada has always been a problem. People would see that I am born in Saudi Arabia, that I am Muslim, my family is all Muslim, so based on that they spend a lot of time going through our belongings or doing security checks. The reason why I see it as unfair is that we have been Canadians for 18 years without a blemish or any bad records.

The identification of place of birth on passports was raised as a common concern by participants. They felt that attempts of differentiate between citizens born in Canada and those who hold citizenship through naturalization resulted in different legal protections, at the border.

Our findings point to how the border is a site where citizenship, even though established and documented on passports, becomes contested. Participants were particularly outraged when their citizenship was questioned by Canadian border authorities. Crossing through U.S. borders was identified as the site where their Canadian citizenship was most often challenged. The U.S./Canada border has always been constituted differently depending on the racialized bodies that pass through it (Bhandar 2008), and our participants acknowledged that before 9/11, they had 
on some occasions experienced discrimination at the U.S. and Canadian borders. Despite this, there was a general presumption among our participants that the Canada-U.S. border is assumed to be a "friendlier" more fluid one, where citizens in each country enjoy relative ease of movement (particularly, in relation to other borders, for example, the India/ Pakistan or U.S./Mexican border). Therefore what this group found most disturbing was the speed and rigidity of barriers that restrict movement across the U.S./Canada border for Muslim Canadians since 9/11.

Our interviewees remarked how for Muslims, Canadian citizenship lost its currency in providing them similar ease of entry into the U.S. compared to "white" Canadians. Some participants recounted how they had been turned back at the United States border because they had names similar to individuals on the U.S. no-fly list, while some were refused entry without specified reasons. Others identified how they were permitted entry into the United States after overcoming major challenges. For example, Sakeena, a 24-year-old woman born in Canada to a Pakistani father and a German mother, recalled a "humiliating" and "traumatic" experience of surveillance when she and two friends, a "white" Christian man and a Lebanese Muslim man, tried to cross the border from Vancouver into the United States. The Christian friend was left alone, but the Lebanese friend was strip and cavity searched by US customs, and Sakeena was interrogated for an hour. Similarly, Rashid a 22-year-old man who immigrated to Canada at the age of 14 and comes from India reports how:

A friend of mine was going to a conference in Washington from Vancouver. He went to the border wearing a turban and they stopped him and asked him where he was going. He was taken aside and strip-searched. They detained him for eight hours and then they sent him back to Canada. This happened at the border.

Interviewees recounted how they were often denied entry or experienced excessive delays and difficulties when trying to enter the United States. The consequences for those in our study included disrupted travel plans, inability to visit ill relatives, missed weddings, job interviews and conferences, all of which influenced connection to family and employment prospects. They spoke of how at the U.S. border they were automatically treated as potential security threats rather than members of a neighbouring state that is an ally. They interpreted this as further attempts to vilify their Muslim identity and undermine their Canadian citizenship. While this may be a U.S. concern, these international experiences profoundly impact the formation of Canadian Muslim identity, one's sense of belonging, and recognition as Canadian. 
Because our interviewees are vulnerable to having their citizenship status and rights depleted at borders, it is not surprising that they expressed fear and heightened anxiety related to travelling. Many reported going to airports and land crossings hours earlier than required, in case they were stopped. Samir remarked:

\begin{abstract}
Honestly, I'm a little bit hesitant to fly as much. Like, I feel like I don't want be caught in a bad situation, maybe they're having a bad day, maybe some guy's just going to pull me in. Like, I've heard stories about people being called in and just kind of disappearing... I mean, every time I travel, like before travelling was just like, you're going on a plane. But it's like, "Oh God, what if I get stuck in the airport?" Let me go there four hours early. Let me write a will before I leave. So you never know what's going to happen.
\end{abstract}

Some reported their family members stopped crossing the border and they too considered not traveling to the U.S. because of the demeaning treatment they had been subjected to. Furthermore, because their legal status as Canadian citizens had been eroded, and the border elicited such fear and anxiety, interviewees felt they had to engage in a range of practices to manage their experiences at the border, which they felt other Canadians did not have to, at least not to the same degree.

\title{
Managing Identities
}

The border emerged as a critical space where our participants must negotiate the perceptions of others and their own understandings of themselves as Muslims in order to ensure their security. At the border, they are seen as the risky "Other" - the potential terrorist, the threat to security. This perception conflicts with their own identity as Muslims, which they continually reassert in their daily lives. The dissonance between societal perception and their own understanding of being Muslim results in our interviewees feeling compelled to manage their identity as Muslims but also the constant negotiation operated to solidify their commitment to being Muslim. Hence, in effect Canadian Muslims self-identity is defined and solidified through their experiences as targets of security.

Research on identity formation has documented a resurgence of Muslim identity in response to anti-terrorism and security practices (Nagra 2011; Mythen et al. 2009). Nagra (2011) found that when faced with religious discrimination and racism in the post-9/11 era, many young Canadian Muslims have responded by re-asserting their Muslim identity. According to Nagra (2011), this is the result of their own increased awareness about Islam, as well as their efforts to cope with discrimina- 
tion to and resist the racialization of Islam. Studies conducted in the U.K. and U.S. have similarly documented a strengthening of Muslim identity (Kundnani 2002; EL-Halawany 2003; Peek 2003; Das Gupta 2004; Mythen et al. 2009). For example, Mythen et al. argue that when Muslims are cast as a security threat, the result is a "clear trend toward the solidification of Muslim identities" (2009: 748).

Our findings also support the revival of Muslim religious affiliation. For many of our participants, the experience of being targeted and victimized served to strengthen religious and political aspects of their identities. Some interviewees, about 30 percent, said that their Muslim identity had been a focal part of their identity before $9 / 11$ and remained so. Yet, 68 percent, reported identifying more strongly as Muslim and feeling a deeper connection to their faith in the post-9/11 era. Saud, a 22-year-old man born in Canada to a Pakistani family reported the following:

I think that largely $9 / 11$ did change how I saw myself as a Muslim...It has made me more aware of the nature of Islam. It has made me more aware of myself as a Muslim. My general awareness has increased. My involvement with Islam increased.

Similarly, Zora, a 22-year-old woman who was born in Bangladesh and came to Canada when she was eight told us:

I am sure there are Muslims that have decided to abandon their own faith [after 9/11]. However, I believe many Muslims have decided to become more educated about their own faith because they realize this is a time where they have to protect their faith. So, in some ways, I believe that many Muslims have become more religious.

Several participants reported becoming more involved in their Muslim communities, educating others about Islam, acting as ambassadors of Islam, wearing traditional Muslim clothes, or becoming more politically active.

However, this renewed religious revival acts as a marker of risk at airports and borders; it becomes a target of the new architecture of security. At the border, expressions of Muslim identity are redefined as a security threat, thereby, compromising their own sense of safety and security. Within these sites, they lose any right to contest the negative constructions of the Muslim "Other." Interviewees referred to their need to limit their self-expression. For example, Radi, a 25-year-old man born in Canada to a Pakistani family, said that since $9 / 11$, he has proudly declared his Muslim identity at public places like the mall and his university campus, because he wanted people to know that he will not be 
"drawn away from his faith" and that "the real Islam is not what happened at 9/11." However, the opposite was true at airports and borders, where he tried to conceal his Muslim identity:

Well, we were all told by our fathers, "If you're going to travel, wear a suit. If you have to keep that beard, trim it down as low as you can. Look as Canadian as you possibly can."

While members of other religions may express their religious beliefs more freely at borders, expressions of Muslim identity produced vulnerability and increased the likelihood of being subjected to invasive interventions and victimization. As a result, our participants found themselves in positions, where they had to manage their identity as Muslims; an identity which is inscribed as risky at the border.

Our interviews focused specifically on borders, but other studies have documented how Muslim identities are managed in everyday life. Scholars have identified processes of "managing identities" (Ahmed and Spalek 2011), "self-regulation" (Mythen et al 2009), "self-disciplining" of behaviour (Naber 2006), and "performing safety" (Mythen et al. 2011). They have documented how Muslims are often pressured to conform to practices that are considered "safe," such as wearing Western clothing, speaking English, and refraining from wearing the hijab or jubba (robe) (Mythen et al 2011: 749). We draw on this literature to understand how our participants engaged in a variety of practices to manage their identity and perform as safer Muslim subjects.

Our participants identified how they attempted to perform and look as "safer" subjects by looking less Muslim and more "Western" at borders. When asked how they manage their appearance, many referred to trying to look more appealing and less threatening by downplaying their religious identity or neutralizing it in ways that they thought would minimize their appearance as a security threat. Several participants discussed changes to their appearance, including trimming beards. For example, Zaahir, mentioned that "I shave my beard when flying because a beard combined with a certain behavior might make it more obvious that you are Muslim." Similarly, Aly, a 19-year-old man who had immigrated to Canada from Bangladesh two years prior said,

My father, when he came to America, he trimmed down his beard because you know what you have to face. You can't fight against something like this. You are going into their country, so you have to do what they tell you to do. When I travel internationally, my dad tells me to shave properly and to look decent and that is what I do. 
A critical decision for women was whether or not to wear the hijab while travelling. Several interviewees referred to struggling with whether it was acceptable to occasionally abandon the hijab; others recounted the experiences of family members who had decided that the hijab was far too risky while traveling. For instance, Amineh, a hijab-wearing, 23-year-old woman born in Canada to a Libyan family mentioned the following:

My mom takes it [the hijab] off. The first time she took it off was a few weeks ago, and she just wore a hat. And she was, like, there was a huge difference in the way she was treated. My mom has been harassed a lot more than I have. They have held her up for an hour and grilled her and, honestly, all sort of stuff. Honestly, my mom has been through a lot more than I have. So my mom has had a lot of bad experiences. So this time she just did not feel like going through it, so she just took it off, and she said, like, no one bothered her, and no one harassed her. None of the border people said anything.

In sum, many of our interviewees reported trying to hide their Muslim identity and instead adopted what Hage (2000) referred to as "national capital" - nationally valued social and cultural preferences - to avoid harassment and intrusive surveillance. In this respect, the border becomes an area where cultural similarities with western culture are rewarded and any affiliation with Islam is punished. Surveillance at the border then goes beyond performing security checks, it also functions to force Muslims to give up symbols of their religious roots and follow the social norms of North American society.

However, some interviewees indicated they refused to alter their appearance, because they felt doing so disrespected their religion. At the same time, they also engaged in alternative practices of self-regulation in an effort to manage their outward Muslim identity. Samir refused to shave his beard, but did modify his clothing:

I don't shave my beard when I travel. I don't really choose to alter my religion for other people. I keep a beard because I feel like it's something that I want to do. If it is going to get me stopped, I will get stopped. I'm not going to change my lifestyle, but at the same time, I will be more careful of what I say and what I wear. You don't want to look suspicious, you don't want to avoid eye contact, at the same time, you don't want be staring at somebody because it might be seen as being suspicious. And I am not going to travel in traditional clothing. Although I choose to wear traditional clothing at times, I'm not going to travel in it because it's not going to make it any easier for me. 
While Atiya's parents asked her to remove her hijab when travelling, she instead uses colours to make her look less foreign and more appealing to security personnel. Atiya a hijab-wearing, 31-year-old woman who was born in Canada and comes from an Indian-Fijian background indicated that:

I will not wear the black scarf because that always has negative connotations. Um, and also pink lipstick seems to help because it looks friendly, like light colours and pastel colour. It is less intimidating and foreign. The image they get of a Muslim woman is in all black and, yes, colours really seem to help with travel.

Changes in appearance and behaviour are illustrative of the self-regulatory practices that our participants are forced to engage in order to reduce the likelihood of triggering heightened suspicion by border workers.

\section{No Mechanism for Complaint}

The fact that most of our participants felt the need to alter their identity illustrates how vulnerable they feel when crossing borders. Interviewees reported feeling powerless and as having little recourse to challenge their targeting and vulnerability at the border. They reported feeling forced to comply with state surveillance practises that they perceive as discriminatory. For instance, Barkat, a 30-year-old man who came to Canada as a child from South Africa, and Samir told us:

I was asked all sorts of weird questions at the airport... And a whole bunch of other really bizarre questions that I just wasn't even expecting at all. But again I complied instead of, "Why the hell are you asking me this for?" I really wanted to. There was this voice inside me that says: "Ask him why?!" But I didn't do it because you don't want them to detain you because you're being difficult, so you just go ahead and answer their questions in as few words as possible and move on. (Barkat)

I think you just tend to comply, because if you don't comply it's kind of seen as, "Oh, what's he hiding?" So you just kind of comply, you have no other choice. What do you want to do? You don't want to get detained, right? (Samir)

Some interviewees said that the extra searches have become routine, and that complaining only prolongs the experience. As Leela, a 20-year-old Muslim woman who was born in Canada and comes from an IndianEast African background noted, "I just go with the flow. Like what are 
you going to do, argue with them every time?" Yet others said that they would like to complain, but did not know how. Fahad, a 28-year-old man who immigrated to Canada from Syria at the age of 14 said, "I haven't actually complained, and my brother also has not, because there is nobody to call and complain to. I don't know who I'd complain to, and I don't think it would change anything."

Interviewees also said that complaints did not always yield favourable results. For instance, Amineh reported that the following happened when her father tried to complain to the government after her family was harassed at the border:

My dad actually asked for an explanation for an investigation from the commission that deals with discrimination in $\mathrm{BC}$. We have it at home. They sent back the report saying that "there was no discrimination there." But they quoted an officer saying that "I saw that they looked very Islamic so I pulled them over just to make sure." If that is not discrimination than what is? They quoted the officer saying that but they still said they found no evidence of discrimination.

For the most part, interviewees comply with airport and border personnel even though they feel their rights are being violated. Not wanting to be detained further, fear of being refused entry to a country to which they are travelling, avoiding being tricked by security personnel, and not knowing who to complain to, all result in the silencing Muslim communities. The lack of formal channels for questioning or lodging complaints operates to render invisible the extent of racial profiling and its consequences, but it also functions to silence and discipline Muslim Canadians into compliance. Even when some of the interviewees may attempt to speak out against their mistreatment, their complaints may not be taken seriously by the government, further eroding their sense of citizenship.

\section{Conclusions}

Like other western nations, this securitization of the Canadian border is increasingly justified through a highly racialized discourse that conceives of Muslims as a threat to western civilizations. As a result, Muslim identities have become the new targets of the architecture of security, placing Muslims in precarious positions as they navigate through airports and borders. Borders in North America are sites where Muslim identities become targets of political processes that compromise humanity, human rights and principles of liberalism. For Muslims in our study, the border is experienced as a "state of exception" (Agamben 2005) 
where due process rights and legal protections can be stripped away at random and, where Muslims' Canadian citizenship is undermined and their religious identity vilified.

The level of mistreatment recounted by our interviewees suggests that as a group, they are subject to excessive forms of restriction and unfair treatment. Young Canadian Muslims referred to the fear of being singled out, questioned, and subjected to intrusive security measures such as strip-searches, detention, being placed on no-fly lists, and being denigrated and humiliated by border staff. The recounted the frequent experiences of being yelled at, demeaned in public and in front of family members. They feared for their family and friends and, particularly, the long-term impact on their children. For them, the border was not simply a site where they become the subject of racialized surveillance; it is experienced as an unpredictable, dangerous location where new technologies and practices are used to justify and mask a different level of humanity and legal protections for Muslims. As our interviews document, our participants experienced surveillance as a direct attack on their Muslim identities and an erosion of their Canadian citizenship. While in their everyday lives our interviewees made attempts to resist the racialization of Islam by asserting their religious identities, airports and borders emerge as spheres where they fear expressing their Muslim identities because this is where their civil liberties are most at risk. For them, security is not a right, but rather a racialized practice of punishment, condescension and derogation.

\section{REFERENCES}

Aas, Katja Franko. 2011. “ 'Crimmigrant' Bodies and Bona Fide Travelers: Surveillance, Citizenship and Global Governance." Theoretical Criminology 15 (3):331-346.

Abbas, Tahir. 2005. Muslim Britain: Communities under Pressure. New York: Zed Books.

Agamben, Giorgio. 2005. State of Exception. Chicago: University of Chicago Press.

Ahmad, Muneer. 2002. "Homeland Insecurities: Racial Violence the Day after September 11." Social Text 20 (3):101-115.

Ahmed, Sara. 2000. Strange Encounters: Embodied Others in Post-Coloniality. New York: Routledge.

Ahmed, Shamila and Basia Spalek. 2011. "(In)Security, Risk, Muslim Communities, Policing and the 'New Terrorism," in Whose Criminal Justice? 
State or Community, edited by Katherine Doolin et al. Sherfield Gables: Waterside Press Ltd.

Akram, Susan M. and Kevin Johnson. 2002. "Race, Civil Rights, and Immigration Law after September 11, 2001: The Targeting of Arabs and Muslims." Annual Survey of American Law 58 (3):295-355.

Alexander, Claire E. 2000. The Asian Gang: Ethnicity, Identity, Masculinity. Oxford: Berg.

Anderson, Kay. 1991. Vancouver's Chinatown: racial discourse in Canada, 1875-1980._Montreal: McGill-Queen's University Press.

Arat-Koc, Sedef. 2005. “The Disciplinary Boundaries of Canadian Identity after September 11: Civilizational Identity, Multiculturalism, and the Challenge of Anti-Imperialist Feminism." Social Justice 32 (4):32-49.

Bahdi, Reem. 2003. "No Exit: Racial Profiling and Canada's War against Terrorism." Osgoode Hall Law Journal 41 (2/3):293-317.

Bannerji, Himani. 2000. The Dark Side of the Nation Essays on Multiculturalism, Nationalism, and Gender.Toronto: Canadian Scholars' Press, 2000.

Bhandar, Davina. 2008. "Resistance, detainment, asylum: The onto-political limits of border crossing in North America." Pp. 281-302 in War, Citizenship, Territory, edited by D. Cowen. New York: Routledge.

Bhabha, Faisal. 2003. "Tracking 'Terrorists' or solidifying Stereotypes? Canada's Antiterrorism Act in Light of the Charter's Equality Guarantees." Windsor Review of Legal and Social Issues 16 (2003): 95-136.

Black, Debra. June 27 2014. "Immigration experts say Bill C-24 discriminatory and weakens citizenship." The Star. http://www.thestar.com/news/immigration/2014/06/27/immigration experts say bill c24 discriminatory and weakens citizenship.html (Accessed on June 03, 2015).

Brown, Simone. 2012. "Race and survillance." Pp. 72 - 79 in Routledge Handbook of Surveillance Studies, edited by Kirstie Ball et al. London: Routledge.

Butler, Judith. 2004. Precarious Life: The Powers of Mourning and Violence. London; New York: Verso.

Canadian Human Rights Commission. 2011. Human Rights Accountability in National Security Practices: A Special Report to Parliament. Ottawa.

CBC News. September 6, 2011. “Harper says 'Islamicism'biggest threat to Canada." http://www.cbc.ca/news/politics/harper-says-islamicism-biggestthreat-to-canada-1.1048280. (Accessed on September 2014).

Choudhry, Sujit. 2001. "Equality in the Face of Terror: Ethnic and Racial Profiling and s.15 of the Charter." Pp. 367-79 in The Security of Freedom: Essays on Canada's Anti-Terrorism Bill, edited by P. Macklem et al. Toronto: University of Toronto Press. 
Choudhry, Sujit and Kent Roach. 2003. "Racial and Ethnic Profiling: Statutory Discretion, Constitutional Remedies, and Democratic Accountability." Osgoode Hall Law Journal 41(1):1-36.

Chandrasekhar, Charu. 2003. "Flying While Brown: Federal Civil Rights Remedies to Post 9/11 Airline Racial Profiling of South Asians." Asian Law Journal 10 (20): 215-251.

Cunningham, Hilary. 2004. "Nations Rebound?: Crossing Borders in a Gated Globe." Identities: Global Studies in Culture and Power 11 (3):329-350.

Cunningham, Hilary and Josiah Heyman. 2004. "Introduction: Mobilities and Enclosures at Borders." Identities: Global Studies in Culture and Power 11 (3):289-302.

Das Gupta, Monisha. 2004. "A View of Post-9/11 Justice from Below.” Peace Review 16 (2):141-148.

Dua, Enakshi. 2000. “The Hindu Woman's Question': Canadian Nation Building and the Social Construction of Gender for South Asian-Canadian Women." Pp. 55-72 in Anti-Racist Feminism, edited by A. Calliste et al. Halifax: Fernhood Publishing.

El-Halawany, H. 2003. "Highly educated Egyptian women's responses to gender challenges in post-9/11 America." Dissertation Abstracts International 64(7): 2658-A.

Fekete, Liz. 2004. "Anti-Muslim Racism and the European Security State." Race and Class 46 (1):3-29.

Forcese, Craig and Kent Roach. June 9, 2015. "Why Can't Canada Get National Security Laws Right?.” Walrus Magazine. http://thewalrus.ca/why-cantcanada-get-national-security-law-right (Accessed on June 20, 2015).

Forcese, Craig. (2014). "A Tale of Two Citizenships: Citizenship Revocation for 'Traitors and Terrorists'." Queen's Law Journal, 39(2): 551-585.

Fuller, Gillian and Ross Harley. 2004. Aviopolis: A Book about Airports. London: Blackdog.

Frances, Henry and Carol Tator. 2006. Racial Profiling in Canada Challenging the Myth of "a Few Bad Apples". Toronto: University of Toronto Press.

Hage, Ghassan. 2000. White Nation: Fantasies of White Supremacy in a Multicultural Society. New York, N.Y. Routledge; Pluto Press.

Hameed, Yavar and Baljit Nagra. 2015. "Bill C-51 will worsen the Racial Profiling of Muslim Canadians." Ricochet. https://ricochet.media/en/364/ bill-c-51-will-worsen-racial-profiling-of-muslim-canadians (Accessed on June 15, 2015).

Helleiner, Jane. 2012. "Whiteness and Narratives of a Racialized Canada/Us Border at Niagara.” Canadian Journal of Sociology 37 (2):109-135. 
Helleiner, Jane. 2010. "Canadian Border Resident Experience of the "Smartening" Border at Niagara." Journal of Borderlands Studies 25 (3-4):87103.

Helly, Denise. 2004. "Are Muslims Discriminated against in Canada since September 2001?" Canadian Ethnic Studies 36 (1):24-47.

Hiller, Harry H. 2010. "Airports as Borderlands: American Preclearance and Transitional Spaces in Canada." Journal of Borderlands Studies 25 (34):19-30.

Howard, Russel and Reid Sawyer. 2004. Terrorism and Counter-Terrorism: Understanding the New Security Environment. Guilford, CT: McGrawHill/Dushkin.

International Civil Liberties Monitoring Group. 2010. Report of the Information Clearinghouse on Border Controls and Infringements to Travellers Rights. $\quad$ http://www.travelwatchlist.ca/updir/travelwatchlist/ICLMG Watchlists_Report.pdf (Accessed June 05, 2015).

Jamil, Uzma and Cécile Rousseau. 2012. "Subject Positioning, Fear, and Insecurity in South Asian Muslim Communities in the War on Terror Context." The Canadian Review of Sociology 49 (4):370.

Krueger, A.B. and D. Laitin. 2008. "A Cross-Country Study of the Origins and Targets of Terrorism." Pp. 148-173 in Terrorism, Economic Development, and Political Openness, edited by P. Keefer et al. New York: Cambridge University Press.

Kundnani, Arun. 2002. "An Unholy Alliance? Racism, Religion and Communalism." Race and Class 44 (2):71-80.

Lyon, David. 2003. Surveillance as Social Sorting. London: Routledge.

Lyon, David. 2006. "Airport Screening, Surveillance, and Social Sorting: Canadian Responses to 9/11 in Context." Canadian Journal of Criminology and Criminal Justice 48 (3):397-411.

Lyon, David. 2008. "Filtering Flows, Friends, and Foes: Global Surveillance." Pp. 29-49 in Politics at the Airport, edited by Mark Salter. Minneapolis. University of Minneapolis Press.

Macklin, Audrey. 2007. "Who Is the Citizen's Other? Considering the Heft of Citizenship." Theoretical Inquiries in Law 8 (2):333-366.

Macklin, Audrey. 2014. "Citizenship Revocation, the Privilege to Have Rights and the Production of the Alien." Queen's Law Journal. 40 (1): 1-54.

Mirza, Munira, Senthilkumaran, Abi Senthilkumaran and Zein Ja'far. 2007. Living Apart Together: British Muslims and the Paradox of Multiculturalism. London: Policy Exchange.

Muller, Benjamin J. 2004. “(Dis)Qualified Bodies: Securitization, Citizenship and 'Identity Management' '. Citizenship Studies 8 (3):279-294. 
Murphy, Christopher. 2007. “ 'Securitizing' Canadian Policing: A New Policing Paradigm for the Post 9/11 Security State?" Canadian Journal of Sociology 32 (4):449-475.

Mythen, Gabe, Sandra Walklate and Fatima Khan. 2009. "'I'm a Muslim, but I'm Not a Terrorist': Victimization, Risky Identities and the Performance of Safety." British Journal of Criminology 49 (6):736-754.

Mythen, Gabe, Sandra Walklate and Fatima Khan. 2013. " 'Why Should We Have to Prove We're Alright?': Counter-Terrorism, Risk and Partial Securities." Sociology 47 (2):383-398.

Naber, Nadine. 2006. "The Rules of Forced Engagement: Race, Gender, and the Culture of Fear among Arab Immigrants in San Francisco Post-9/11." Cultural Dynamics 18 (3):235-267.

Nagra Baljit. 2011. "Our faith was also high jacked by those people: Reclaiming Muslim identity in the post 9/11 era." Journal of Ethnic and Migration Studies 37 (3): 425-441.

Pantazis, Christina and Simon Pemberton. 2009. "From the 'Old' to the 'New' Suspect Community: Examining the Impacts of Recent UK CounterTerrorist Legislation." British Journal of Criminology 49 (5):646-666.

Parliament of Canada, April 23, 2012. Proceedings of the Special Senate Committee on Anti-terrorism "Issue 2 - Evidence - Meeting of April 23, 2012: http://www.parl.gc.ca/content/sen/committee/411/ANTR/02EV49469-e.HTM

Peek, Lori A. 2011. Behind the Backlash: Muslim Americans after 9/11. Philadelphia: Temple University Press.

Poincignon, Yann. 2004. "Civil Aviation and Terrorism: The Birth and Stakes of a European Air Transport Security Policy.” Cultures et Conflits (56):83119.

Poole, Elizabeth. 2002. Reporting Islam: Media Representations of British Muslims. London; New York: I.B. Tauris.

Poynting, Scott and Barbara Perry. 2007. "Climates of Hate: Media and State Inspired Victimisation of Muslims in Canada and Australia since 9/11." Current Issues in Criminal Justice 1 (2): 151-171.

Pratt, Anna. 2010. "Between a Hunch and a Hard Place: Making Suspicion Reasonable at the Canadian Border." Social and Legal Studies 19 (4):461480 .

Pratt, Anna and Sara Thompson. 2008. "Chivalry, 'Race' and Discretion at the Canadian Border.” British Journal of Criminology 48 (5):620-640.

R. v. Simmons [1988] SCC 2 SCR 495

Razack, Sherene. 2008. Casting out the Eviction of Muslims from Western Law and Politics. Toronto: University of Toronto Press. 
Razack, Sherene. 2009. "Afterword: Race, desire, and contemporary security discourses." University of Toronto Quarterly 78(2): 815-20.

Roach, Kent and Sujit Choudhry. 2003. "Racial and Ethnic Profiling: Statutory Discretion, Constitutional Remedies, and Democratic Accountability." Osgoode Hall Law Journal 41 (1):1-36.

Sa'di, Ahmad H. 2012. "Colonialism and surveillance.” Pp. 151 - 158 in Routledge Handbook of Surveillance Studies. London: Routledge.

Said, Edward. 1985. Orientalism. Harmondsworth, Middlesex: Penguin Books.

Salter, Mark B. 2007. "Governmentalities of an Airport: Heterotopia and Confession.” International Political Sociology 1 (1):49-66.

Salter, Mark B. 2008. "When the Exception Becomes the Rule: Borders, Sovereignty, and Citizenship." Citizenship Studies 12 (4):365-380.

Satzewich, Vic and William Shaffir. 2009. "Racism Versus Professionalism: Claims and Counter-Claims About Racial Profiling." Canadian Journal of Criminology and Criminal Justice 51 (2):199-226.

Sharma, Nandita. 2006. "White nationalism, illegality and imperialism: Border controls as ideology." Pp. 121-143 in K. Hunt Gendering the War on Terror: War Stories and Camouflaged Politics, edited by K. Hunt. Aldershot: Ashgate.

Simpson, Audra. 2008. "Subjects of Sovereignty: Indigeneity, the Revenue Rule, and Juridics of Failed Consent." Transdisciplinary Conflict of Laws 71 (3):191-215.

Spencer, Alexander. 2006. "Questioning the Concept of 'New Terrorism'." Peace Conflict and Development 8: 1-33.

Statistics Canada. 2011. 2011 National Household Survey. http://www.statscan. ca/. (Accessed on May 20, 2015).

Tanovich, David M. 2006. The Colour of Justice: Policing Race in Canada. Toronto: Irwin Law.

Thobani, Sunera. 2007. Exalted Subjects Studies in the Making of Race and Nation in Canada. Toronto: University of Toronto Press.

Zedner, Lucia. 2010. "Security, the State, and the Citizen: The Changing Architecture of Crime Control." New Criminal Law Review 13 (2):379-403.

Zine, Jasmin. 2012. Stolen Youth: Lost Boys and Imperial Wars. Pp.390-449 in Omar Khadr: Oh Canada, edited by J.Williamson. Montreal \& Kingston: McGill-Queen's University Press. 
Dr. Baljit Nagra is an Assistant Professor in the Department of Criminology at the University of Ottawa. She was previously a SSRHC (Social Sciences and Humanities Research Council) postdoctoral research fellow in the Department of Equity Studies at York University. She received her PhD from the University of Toronto in 2011. She teaches and researches in the following areas of Race Relations, Security and Surveillance, Gender and Multiculturalism.

E-Mail: bnagra@uottawa.ca

Paula Maurutto is an Associate Professor in the Department of Sociology and the Centre of Criminology and Socio-legal Studies at the University of Toronto. Her work examines the intersection between social policy and criminal justice. She has published in the area of punishment, risk theory, surveillance and the non-profit sector. Her current project examines how specialized courts are reshaping understandings of punishment, risk and legal practice.

E-Mail: p.maurutto@utoronto.ca 